\title{
SUMMER HABITAT SELECTION OF REINDEER (Rangifer tarandus) GOVERNS ON THE UNPROTECTED FOREST AND HUMAN INTERFACE IN CHINA
}

\author{
JING WANG ${ }^{1,2}$, PENG WANG ${ }^{1,2}$, ACHYUT ARYAL $^{3}$, XIUXIANG MENG ${ }^{1,2 *}$, ROBERT B. \\ WELADJI ${ }^{4}$
}

${ }^{1}$ School of Environment and Natural Resources, Renmin University of China, 59 Zhongguancun Dajie, Beijing 100872, China; e-mail: meng2014@ruc.edu.cn

${ }^{2}$ College of Animal Science and Veterinary Medicine, Shanxi Agricultural University, Taigu 030801, China

${ }^{3}$ Institute of Natural and Mathematical Sciences, Massey University, Auckland, New Zealand.

${ }^{4}$ Department of Biology, Concordia University, 7141 Sherbrooke Street West, Montreal, QC, H4 B 1R6, Canada

${ }^{*}$ Author for correspondence

\begin{abstract}
Wang J., Wang P., Aryal A., Meng X., Weladji R.B.: Summer habitat selection of reindeer (Rangifer tarandus) governs on the unprotected forest and human interface in China. Ekológia (Bratislava), Vol. 37, No. 2, p. 112-121, 2018.

The habitat selection by animals depends on different environmental and anthropogenic factors such as the season, climate, and the life cycle stage. Here, we have presented the summer habitat selection strategy of reindeer (Rangifer tarandus) in the unprotected forest area from the northern arctic region of China. In summer 2012, we investigated a total of 72 used and 162 non-used plots in the reindeer habitat to record habitat variables. We found that the reindeer used significantly higher altitude, arbour availability, and vegetation cover area as compared to the non-used habitat variables. Principal component analysis (PCA) showed that six principal components (68.5\%) were mainly responsible for the summer habitat selection of reindeer such as the slope position, concealment, anthropogenic dispersion, arbour species, distance from the anthropogenic disturbance area $(>1000 \mathrm{~m}$ ) and water quality (Wilks' Lambda $=0.12 ; \mathrm{P}=0.0001$ ). The local people are largely dependent on forest product resource in these regions, such as bees herding, collecting wild vegetables, hunting, poaching, and grazing. These activities highly influenced the reindeer habitat and its behaviours. This study thus confirmed that reindeers are forced to choose poor habitat in unprotected forest area with high human disturbance or interference. These factors should be considered by the concerned authority or agency to manage reindeer population in the wild.
\end{abstract}

Key words: reindeer (Rangifer tarandus), summer, habitat selection, effective factor.

\section{Introduction}

Habitat selection by animal is a process of long-term evolution and function adopted by the animal to survive in the existing environment, based on the natural selection theory (Manly et al., 2002; Boyce et al., 2002). Habitat selection of species is also dependent on habitats and 
animal behaviour (Aryal et al., 2013a, 2014b) and the ongoing changes in the environment may also affect the habitat selection by an animal (Aryal et al., 2013b). Habitat selection by an animal differs with season, climate, and the animal life cycle (Jiang, 2004; Aryal et al., 2014a).

Reindeers (Rangifer tarandus) are least concerned species distributed in the northern arctic region of China (Ma, 1986; Henttonen, Tikhonov, 2008) as well as in Eurasia and North America (Banfield, 1961; Orians, Wittenberger, 1991). The reindeer population in China is of great interest with the Ewenki community in terms of promoting tourism, providing antler, and also as a food source (Ma, 1986); however, information on the impact of their use on their behaviour, distribution, and response to environmental stress is lacking (Yin et al., 1999; Tang, 2008; Wang, 1995; Li, 1988). The reindeer has seasonal migration in different habitat, and there are very few studies that have reported on the habitat selection of this animal in the other distribution ranges (OBrian et al., 2006; Skarin et al., 2004). However, specifically, the Chinese reindeer population has not been uniformly managed, and studies on their seasonal habitat preference throughout the distribution range in China is lacking (Ma, 1986; Yin et al., 1999; Tang, 2008; Wang, 1995; Li, 1988). Reindeer in China are distributed outside the protected area, in the unprotected forest. Therefore, we have attempted to study the summer habitat selection strategy of reindeer in the unprotected forest area of the northern China.

\section{Material and methods}

\section{Study area}

The study was conducted in Aoluguya, Genhe, Inner Mongolia, China $\left(52^{\circ} 10^{\prime} \mathrm{E}, 5^{\prime} 122^{\circ} \mathrm{N}\right)$ (Fig. 1). This region is located in northern China and in the western slope of the Great Khingan Range, which is a hilly terrain with plateau-dominated habitat (Ma, 1985). The study area had an altitude ranging from 700 to $1443 \mathrm{~m}$ (Fig. 1) and it was covered with larch tree forest including pine, birch, and red spruce trees (Chen, 1985; Feng, Bai, 2011). This forest area has a humid cold temperate climate, which is characterized by cold, wet winter; long, dry, and windy spring; cool short summer; and plunged autumn temperatures with early frost. The annual average temperature and precipitation here is $6.5^{\circ} \mathrm{C}$ and $450 \mathrm{~mm}$, respectively (Chen, 1985; Xiang, 2008). This area boasts of about 40 mammalian species including reindeer, musk deer (Moschus moschiferus), black brown bear (Ursus arctos lasiotus), bear (Selenarctos thibetanus), lynx (Felis

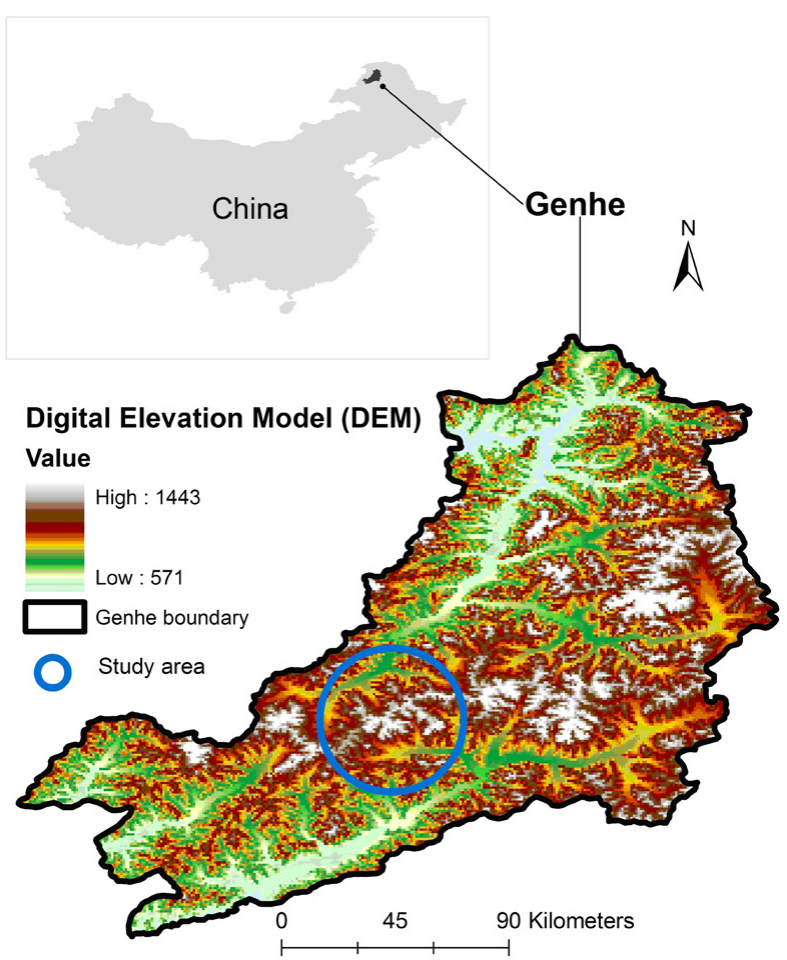

Fig. 1. Illustrated China and study area's digital elevation modelling (DEM) within Genhe district of China. 
T a b l e 1. Definition and description of habitat variables of wild reindeer.

\begin{tabular}{|c|c|c|}
\hline Variable & Ecological variables & Variable definition and description \\
\hline \multirow{12}{*}{$\begin{array}{l}\text { Continuous } \\
\text { variables }\end{array}$} & Altitude $(\mathrm{m})$ & $\begin{array}{l}20 \times 20 \mathrm{~m} \text { altitude of the reindeer fresh activity trace centre within sample } \\
\text { area; }\end{array}$ \\
\hline & Arbor canopy (\%) & $\begin{array}{l}\text { estimate } 20 \times 20 \mathrm{~m} \text { sample centre four directions the upper canopy of vegeta- } \\
\text { tion cover on the ground percentage averaged; }\end{array}$ \\
\hline & Arbor DBH & $\begin{array}{l}20 \times 20 \mathrm{~m} \text { sample arbour diameter the four directions from the nearest trees } \\
\text { to centre sample averages (DBH, roughly } 1.3 \mathrm{~m} \text { height); }\end{array}$ \\
\hline & Arbor height $(\mathrm{m})$ & $\begin{array}{l}20 \times 20 \mathrm{~m} \text { sample the four directions from the nearest trees to centre sample } \\
\text { height averages (conifers, DBH }>15 \mathrm{~cm} \text { ); }\end{array}$ \\
\hline & Arbor density (stems) & $20 \times 20 \mathrm{~m}$ Arbor quantity (conifers, $\mathrm{DBH}>15 \mathrm{~cm}$ ); \\
\hline & Shrub height $(\mathrm{m})$ & $\begin{array}{l}\text { average value of brush height of five } 4 \times 4 \mathrm{~m} \text { sample area in the } 20 \times 20 \mathrm{~m} \\
\text { sample area; }\end{array}$ \\
\hline & Shrub canopy (\%) & $\begin{array}{l}20 \times 20 \mathrm{~m} \text { average of Shrub canopy of five } 4 \times 4 \mathrm{~m} \text { sample area in the } 20 \times 20 \mathrm{~m} \\
\text { sample area; }\end{array}$ \\
\hline & $\begin{array}{l}\text { Ground-plant muscus-lichen } \\
\text { cover }(\%)\end{array}$ & $\begin{array}{l}\text { the ratio of surface vegetation accounts for the acreage of sample area in the } \\
20 \times 20 \mathrm{~m} \text { sample area; }\end{array}$ \\
\hline & Muscus-lichen cover (\%) & $\begin{array}{l}\text { estimate the number of eatable plants for reindeer of five } 4 \times 4 \mathrm{~m} \text { sample area } \\
\text { in the } 20 \times 20 \mathrm{~m} \text { sample area, average value; }\end{array}$ \\
\hline & Stump quantity (stems) & $20 \times 20 \mathrm{~m}$ sample Stump quantity(conifers, DBH $>15 \mathrm{~cm}$ ); \\
\hline & Fallen wood quantity (stems) & $20 \times 20 \mathrm{~m}$ sample fallen wood quantity (conifers, $\mathrm{DBH}>15 \mathrm{~cm}$ ); \\
\hline & Withered grass cover $(\%)$ & $\begin{array}{l}20 \times 20 \mathrm{~m} \text { sample hay ratio of the total sample area estimated in each } 4 \times 4 \mathrm{~m} \\
\text { quadrat dry plant total coverage; }\end{array}$ \\
\hline \multirow{11}{*}{$\begin{array}{l}\text { Discrete } \\
\text { Variables }\end{array}$} & Slope aspect & $\begin{array}{l}\text { slope aspect in } 20 \times 20 \mathrm{~m} \text { sample, divided into the east slope }\left(45 \sim 135^{\circ}\right) \text {, the } \\
\text { southern slope }\left(135 \sim 225^{\circ}\right) \text {, the western slope }\left(225 \sim 315^{\circ}\right) \text { and the North } \\
\text { slope }\left(315 \sim 45^{\circ}\right) \text {; }\end{array}$ \\
\hline & Slope gradient $\left({ }^{\circ}\right)$ & $\begin{array}{l}\text { slope gradient in } 20 \times 20 \mathrm{~m} \text { sample, divided into flat slope }\left(\leq 30^{\circ}\right) \text {, middle } \\
\text { slope }\left(30 \sim 60^{\circ}\right) \text { and steep slopes }\left(\geq 60^{\circ}\right) \text {; }\end{array}$ \\
\hline & Slope position & $\begin{array}{l}20 \times 20 \mathrm{~m} \text { sample slope position divided into: the lower slopes and valley, } \\
\text { mesoslope /mountainside, upslope and ridge; }\end{array}$ \\
\hline & Vegetation type & $\begin{array}{l}20 \times 20 \mathrm{~m} \text { sample area vegetation mainly type appearance, divided into conifer } \\
\text { forest, conifer and shrub mixed forest, shrub, grassland; }\end{array}$ \\
\hline & Concealment & $\begin{array}{l}\text { at } 1.3 \mathrm{~m} \text { height (roughly the height of the reindeer head and eye when } \\
\text { upright position), sample the average in four direction of the visual range, } \\
\text { divided into } 3 \text { level, that is good }(\leq 10) \text {, middle }(10 \sim 20 \mathrm{~m}) \text { and poor }(\geq 20) \text {; }\end{array}$ \\
\hline & Lee condition & $\begin{array}{l}\text { sample area affected by the wind, the intrusive is divided into level } 3 \text {, that is } \\
\text { good, middle, bad; }\end{array}$ \\
\hline & Water quantity assessment & $\begin{array}{l}\text { the size of the bubble water in the sample area and around the sample area, } \\
\text { divided into four grade: greatly (diameter of rivers or bubble } \geq 1500 \mathrm{~cm} \text { ), big } \\
\text { (diameter of river branches or bubbles is } \geq 1000 \mathrm{~cm} \text { ), medium (diameter of } \\
\text { river branches or bubbles is } \geq 500 \mathrm{~cm} \text { ), small (diameter of bubbles is }<100 \\
\mathrm{~cm} \text { ); }\end{array}$ \\
\hline & Soil moisture degree & $\begin{array}{l}\text { divided into four grades: very wet (grip will make the water be out of), moist } \\
\text { (grip will make dough), moist to some extent (grip will make dough, scat- } \\
\text { tered if loosen the grip), dry; }\end{array}$ \\
\hline & Water dispersion $(\mathrm{m})$ & $\begin{array}{l}\text { vertical dimension between sample area and source of water (springs and } \\
\text { rivers and so on, do not contain snow), divided into three grade: near }(\leq 500 \\
\mathrm{m}) \text {, medium }(500 \sim 1000 \mathrm{~m}) \text { and far }(\geq 1000 \mathrm{~m}) \text {; }\end{array}$ \\
\hline & Anthropogenic dispersion (m) & $\begin{array}{l}\text { from sample area to human disturbance (such as tourism, transportation, } \\
\text { agriculture, gathering, grazing and so on. divided into three grade: near }(\leq \\
500 \mathrm{~m}) \text {, medium }(500 \sim 1000 \mathrm{~m}) \text { and far }(\geq 1000 \mathrm{~m}) \text {; }\end{array}$ \\
\hline & $\begin{array}{l}\text { Hunters residential area } \\
\text { dispersion }(\mathrm{m})\end{array}$ & $\begin{array}{l}\text { vertical dimension between sample area and settlement, divided into three } \\
\text { grade: near }(\leq 500 \mathrm{~m}) \text {, medium }(500 \sim 1000 \mathrm{~m}) \text { and far }(\geq 1000 \mathrm{~m}) \text {. }\end{array}$ \\
\hline
\end{tabular}


lynx), sable (Martes zibellina), and snowshoe hare (Lepus timidus) (Chen, 1985). The local people largely depend on the forest for their livelihood such as by collecting forest products, grazing, herding bees, collecting wild vegetables as well as by related activities such as tourism and hunting (Chen, 1985; Liao, Xie, 2011).

\section{Data collection}

We laid out eights transect lines in the reindeer habitat in summer 2012 (June-July). The transect line were laid from an elevation of 400 to $1400 \mathrm{~m}$ with a width of $1000 \mathrm{~m}$ between each transect. We walked in each transect line to search for reindeer signs (direct observation, pellets, footprints, resting site, urine deposition site, and mark). Once we encountered any sign, we laid out reindeer use plots of $20 \times 20 \mathrm{~m}$ and recorded all habitat information (Table 1). At every $100 \mathrm{~m}$ stop, we laid out same-sized plots 50 step to the right and to the left of the transects and searched again for reindeer signs. In case we did not find any signs, we labelled the plot as non-use plot and collected same habitat variables. We used principal components analysis (PCA) and discriminate function analysis (DFA) to analyse the habitat selection function of reindeers in the study area based on the presence and absence of habitat data (Manly et al., 2002). We then performed our analysis by using SPSS (version 16.1) software.

\section{Results}

We measured a total of 72 use and 162 non-use sample plots in the reindeer habitat and recorded the habitat variables for summer season (Table 1). Continuous variables of habitat such as higher altitude, arbour availability, and ground cover were significantly different between use and non-use plots (Mann-Whitney $\mathrm{U}, \mathrm{P}<0.005$ ); other continuous variables were not significantly different between the use and non-use plots (Mann-Whitney U, P > 0.005) (Table 2).

There was a significant difference in the discrete variables between use and non-use plots such as slope $\left(\chi^{2}=11.675, \mathrm{df}=3, \mathrm{P}=0.009\right)$. Furthermore, the variables such as vegetation type, concealment, lee condition, water quantity assessment, soil moisture degree, water dispersion, and anthropogenic dispersion distance variables were also significantly different

$\mathrm{T}$ a b l e 2. Continuous summer habitat variable in use and non-use plots in the study area (Mean \pm S.E.).

\begin{tabular}{|l|c|c|c|}
\hline Variables & $\begin{array}{c}(\mathbf{n}=\mathbf{7 2}) \\
\text { Use plots }\end{array}$ & $\begin{array}{c}(\mathbf{n}=\mathbf{1 6 2}) \\
\text { Non- use plots }\end{array}$ & $\begin{array}{c}\text { P } \\
\text { Mann-Whitney U test }\end{array}$ \\
\hline Altitude & $926.92 \pm 0.81$ & $913.35 \pm 1.34$ & $0.000^{* *}$ \\
\hline Arbor canopy & $17.86 \pm 2.40$ & $9.42 \pm 1.46$ & $0.000^{* *}$ \\
\hline Arbor DBH & $35.54 \pm 2.11$ & $15.99 \pm 1.31$ & $0.000^{* *}$ \\
\hline Arbor density & $8.21 \pm 0.46$ & $4.30 \pm 0.37$ & $0.000^{* *}$ \\
\hline Arbor density & $6.94 \pm 0.49$ & $4.39 \pm 0.49$ & $0.000^{* *}$ \\
\hline Shrub canopy & $59.38 \pm 2.38$ & $57.35 \pm 1.90$ & 0.794 \\
\hline Shrub height & $54.16 \pm 1.98$ & $121.61 \pm 7.04$ & $0.000^{* *}$ \\
\hline Ground-plant cover & $90.50 \pm 0.73$ & $91.31 \pm 0.57$ & 0.023 \\
\hline muscus-lichen & $19.37 \pm 1.69$ & $15.34 \pm 0.97$ & 0.849 \\
\hline Stump quantity & $1.31 \pm 0.22$ & $0.98 \pm 0.16$ & $0.000^{* *}$ \\
\hline fallen wood quantity & $1.22 \pm 0.23$ & $1.31 \pm 0.20$ & 0.128 \\
\hline Grassland cover & $2.57 \pm 0.36$ & $5.11 \pm 0.34$ & $0.013^{*}$ \\
\hline
\end{tabular}

Notes: ${ }^{\star}$ Significant difference $(P<0.05) ;{ }^{* \star}$ Most significant difference $(P<0.01)$. 
T a b l e 3. Discrete summer habitat variable in use and non-use plots in the study area.

\begin{tabular}{|c|c|c|c|c|c|}
\hline \multirow[b]{2}{*}{ Factor } & \multirow[b]{2}{*}{ Item } & \multicolumn{2}{|c|}{ Frequency } & \multicolumn{2}{|c|}{ Percentage (\%) } \\
\hline & & $\begin{array}{l}\text { Random plots } \\
(\mathrm{n}=162)\end{array}$ & $\begin{array}{c}\text { Used sites } \\
(n=72)\end{array}$ & $\begin{array}{l}\text { Random plots } \\
(n=162)\end{array}$ & $\begin{array}{c}\text { Used sites } \\
(\mathbf{n}=72)\end{array}$ \\
\hline \multirow{5}{*}{ Slope aspect } & East & 76 & 39 & 46.9 & 54.2 \\
\hline & West & 2 & 0 & 1.2 & 0 \\
\hline & South & 26 & 1 & 16 & 1.4 \\
\hline & North & 58 & 32 & 35.8 & 44.4 \\
\hline & \multicolumn{5}{|c|}{$\chi^{2}=11.675 \mathrm{df}=3 \quad \mathrm{P}=0.009$} \\
\hline \multirow{4}{*}{ Slope gradient } & Flat slope $(0-20)$ & 108 & 16 & 66.7 & 22.2 \\
\hline & Gentle slope (20-40) & 39 & 32 & 24.1 & 44.4 \\
\hline & Steep gradient $(>40)$ & 15 & 24 & 9.3 & 33.3 \\
\hline & \multicolumn{5}{|c|}{$\chi^{2}=42.731 \mathrm{~d} f=2 \mathrm{P}=0.000$} \\
\hline \multirow{4}{*}{ Slope position } & Upslope & 0 & 1 & 0 & 1.4 \\
\hline & Middle slope & 0 & 59 & 0 & 81.9 \\
\hline & down the slope & 162 & 12 & 100 & 16.7 \\
\hline & \multicolumn{5}{|c|}{$\chi^{2}=181.552 \mathrm{~d} f=2 \quad \mathrm{P}=0.000$} \\
\hline \multirow{5}{*}{ Vegetation type } & Needle leaved forest & 49 & 17 & 30.3 & 23.6 \\
\hline & Mixed forest & 77 & 47 & 47.5 & 65.3 \\
\hline & Brush & 24 & 0 & 14.8 & 0.00 \\
\hline & Meadow & 12 & 8 & 7.4 & 11.1 \\
\hline & \multicolumn{5}{|c|}{$\chi^{2}=15.207 \mathrm{~d} f=3 \quad \mathrm{P}=0.002$} \\
\hline \multirow{4}{*}{ Concealment } & Good & 24 & 0 & 14.8 & 0 \\
\hline & Fair & 25 & 3 & 15.4 & 4.2 \\
\hline & Poor & 113 & 69 & 69.8 & 95.8 \\
\hline & \multicolumn{5}{|c|}{$\chi^{2}=20.313 \mathrm{~d} f=2 \mathrm{P}=0.000$} \\
\hline \multirow{5}{*}{ Lee condition } & Excellent & 39 & 1 & 24.1 & 1.4 \\
\hline & Good & 38 & 6 & 23.5 & 8.3 \\
\hline & Fair & 67 & 29 & 41.4 & 40.3 \\
\hline & Poor & 18 & 36 & 11.1 & 50 \\
\hline & \multicolumn{5}{|c|}{$\chi^{2}=53.750 \mathrm{~d} f=3 \quad \mathrm{P}=0.000$} \\
\hline \multirow{5}{*}{$\begin{array}{l}\text { water quantity } \\
\text { assessment }\end{array}$} & Large & 90 & 70 & 55.6 & 97.2 \\
\hline & Quite large & 20 & 2 & 12.3 & 2.8 \\
\hline & Middle & 11 & 0 & 6.8 & 0 \\
\hline & Small & 41 & 0 & 25.3 & 0 \\
\hline & \multicolumn{5}{|c|}{$\chi^{2}=40.621 \mathrm{~d} f=3 \quad \mathrm{P}=0.000$} \\
\hline \multirow{5}{*}{ Soil moisture degree } & Extremely moist & 48 & 0 & 29.6 & 0.0 \\
\hline & Moist & 81 & 33 & 50.0 & 45.8 \\
\hline & Dry & 21 & 39 & 13.0 & 54.2 \\
\hline & Extremely dry & 12 & 0 & 7.4 & 0.0 \\
\hline & \multicolumn{5}{|c|}{$\chi^{2}=59.848 \mathrm{~d} f=3 \quad \mathrm{P}=0.000$} \\
\hline \multirow{4}{*}{ Water dispersion } & Far & 117 & 51 & 72.2 & 70.8 \\
\hline & Middle & 32 & 21 & 19.8 & 29.2 \\
\hline & Near & 13 & 0 & 8 & 0 \\
\hline & $\chi^{2}=7.741 \mathrm{~d} f=2 \quad \mathrm{P}=0.021$ & & & & \\
\hline & Far & 162 & 43 & 100 & 59.7 \\
\hline Anthropogenic & Middle & 0 & 29 & 0 & 40.3 \\
\hline dispersion & Near & 0 & 0 & 0 & 0 \\
\hline & & $\chi^{2}=74$ & $\mathrm{~d} f=1 \quad \mathrm{P}=0$. & & \\
\hline & Far & 62 & 18 & 38.3 & 25 \\
\hline Hunters residential & Middle & 71 & 51 & 43.8 & 70.8 \\
\hline area dispersion & Near & 29 & 3 & 17.9 & 4.2 \\
\hline & & $\chi^{2}=16$ & $\mathrm{~d} f=2 \mathrm{P}=0.0$ & & \\
\hline
\end{tabular}

Notes: ${ }^{\star}$ Significant difference $(P<0.05) ;{ }^{*}$ Highly significant difference $(P<0.01)$. 
between the use and non-use plots (Table $3, \mathrm{P}<0.05)$. In the summer, the reindeers used more mixed-shrub vegetation type area $\left(65.3 \% ; \chi^{2}=15.207, \mathrm{df}=3, \mathrm{P}=0.002\right)$, concealment $(95.8 \% ; \mathrm{P}=0.001)$, lee condition $(50 \% ; \mathrm{P}=0.001)$, large amount of water $(97.2 \% ; \mathrm{P}=$ $0.021)$, soil moisture partial drying $(54.2 \%)$, distance from the nearest water source $(\geq 1000$ $\mathrm{m}, 70.8 \% ; \mathrm{P}=0.001)$, human disturbance distance $(\geq 1000 \mathrm{~m}, 59.7 \% ; \mathrm{P}=0.001)$, distance from the hunter's residential area dispersion $(\geq 500 \mathrm{~m}, 95.8 \% ; \mathrm{P}=0.001)$ habitats (Table 3 ).

Principal component analysis (PCA) revealed that 6 principal components could explain $68.5 \%$ of the total variance among all habitat variables (variables in 6 metrics; Table 4). First line of PCA represented arbour (eigen values cumulative 21\%); second line represented lichen cover, shrubs height, and canopy (eigen values cumulative 36\%); third line represented water quality; and the fourth and fifth lines represented the stump quality and fallen trees (eigen values cumulative 68\%) (Table 4).

T a b l e 4. Principal component analysis (PCA) coefficients of 23 reindeer habitat variables in the study area (Variability explained $68.5 \%$ ).

\begin{tabular}{|l|c|c|c|c|c|c|}
\hline \multirow{2}{*}{ Variable } & \multicolumn{7}{|c|}{ Component } \\
\cline { 2 - 7 } & PC1 & PC 2 & PC 3 & PC 4 & PC 5 & PC 6 \\
\hline Altitude & -.171 & .414 & .240 & -.284 & -.267 & .116 \\
\hline Arbor canopy & .771 & .178 & .369 & -.110 & .020 & .095 \\
\hline Arbor DBH & .809 & .036 & .387 & .020 & .085 & -.029 \\
\hline Arbor height & .666 & .077 & .402 & .027 & -.091 & .023 \\
\hline Arbor density & .829 & .145 & .376 & .058 & .023 & .030 \\
\hline Shrub canopy & -.499 & .248 & .140 & .175 & -.154 & -.192 \\
\hline Shrub height & -.523 & .270 & .414 & .267 & .285 & -.075 \\
\hline Ground-plantmuscus-lichen cover & -.108 & .673 & .249 & .077 & -.261 & .081 \\
\hline muscus-lichen cover & .138 & -.544 & .053 & .287 & -.144 & .476 \\
\hline Slope gradient & .361 & -.125 & -.025 & -.354 & .401 & .311 \\
\hline Water dispersion & .396 & .332 & -.489 & .633 & -.133 & .078 \\
\hline Anthropogenic dispersion & .214 & .597 & -.424 & -.338 & .237 & .164 \\
\hline Hunters residential area dispersion & .361 & .431 & -.460 & .608 & -.021 & .143 \\
\hline Concealment & .293 & -.481 & -.240 & -.414 & -.397 & -.036 \\
\hline Slope aspect & -.210 & -.185 & -.060 & .239 & .510 & .452 \\
\hline Vegetation type & -.577 & -.168 & -.342 & -.108 & -.072 & .160 \\
\hline water quantity assessment & -.344 & -.382 & .671 & .074 & -.062 & .146 \\
\hline Lee condition & .325 & -.368 & -.286 & -.119 & -.460 & .242 \\
\hline Stump quantity & .470 & -.254 & -.179 & .371 & .059 & -.461 \\
\hline fallen wood quantity & .278 & -.700 & -.168 & .001 & .331 & -.316 \\
\hline
\end{tabular}

Our result suggested that 6 variables, namely, the slope position, concealment, anthropogenic dispersion, arbour species, hunter distribution area, and water quality, were significantly responsible for summer habitat selection of reindeer in the unprotected forest habitat (Wilks' Lambda $=0.12 ; \mathrm{P}=0.0001$; Tables 5, 6). 
$\mathrm{T}$ a b le 5 . Variables in the analysis summer habitat selection model.

\begin{tabular}{|c|c|c|c|c|}
\hline \multicolumn{2}{|c|}{ Model } & \multirow{2}{*}{$\begin{array}{c}\text { Tolerance } \\
.993 \\
\end{array}$} & \multirow{2}{*}{$\begin{array}{c}\text { F to Remove } \\
559.373 \\
\end{array}$} & \multirow{2}{*}{$\begin{array}{c}\text { Wilks' Lambda } \\
.719\end{array}$} \\
\hline , & Slope position & & & \\
\hline 1 & Concealment & .993 & 33.085 & .240 \\
\hline \multirow{3}{*}{2} & Slope position & .955 & 231.486 & .373 \\
\hline & Concealment & .930 & 45.978 & .223 \\
\hline & Anthropogenic dispersion & .894 & 30.192 & .210 \\
\hline \multirow{3}{*}{3} & Slope position & .954 & 132.159 & .223 \\
\hline & Concealment & .914 & 48.345 & .171 \\
\hline & Anthropogenic dispersion & .625 & 83.337 & .193 \\
\hline \multirow{4}{*}{4} & Slope position & .951 & 129.303 & .212 \\
\hline & Concealment & .891 & 36.075 & .156 \\
\hline & Anthropogenic dispersion & .625 & 79.919 & .182 \\
\hline & Arbor DBH & .966 & 10.908 & .141 \\
\hline \multirow{5}{*}{5} & Slope position & .949 & 111.162 & .191 \\
\hline & Concealment & .869 & 25.964 & .143 \\
\hline & Anthropogenic dispersion & .524 & 95.802 & .182 \\
\hline & Arbor DBH & .948 & 13.510 & .136 \\
\hline & Hunters residential area dispersion & .777 & 12.032 & .135 \\
\hline \multirow{6}{*}{6} & Slope position & .947 & 105.198 & .176 \\
\hline & Concealment & .815 & 13.515 & .127 \\
\hline & Anthropogenic dispersion & .524 & 84.306 & .165 \\
\hline & Arbor DBH & .945 & 14.247 & .128 \\
\hline & Hunters residential area dispersion & .580 & 24.622 & .133 \\
\hline & water quantity assessment & .609 & 15.065 & .128 \\
\hline
\end{tabular}

T a b l e 6. Wilk's lambda of governing factors for habitat selection of reindeers.

\begin{tabular}{|c|c|c|c|c|c|c|c|c|c|}
\hline \multirow{2}{*}{ Model } & \multirow{2}{*}{$\begin{array}{c}\text { Number } \\
\text { of Variables }\end{array}$} & \multirow{2}{*}{ Lambda } & \multirow{2}{*}{$\mathbf{d f 1}$} & \multirow{2}{*}{$\mathbf{d f 2}$} & \multirow{2}{*}{$\mathbf{d f 3}$} & \multicolumn{4}{|c|}{ Exact F } \\
\cline { 7 - 12 } & & & & & Statistic & df1 & df2 & Sig. \\
\hline 1 & 2 & .210 & 2 & 1 & 232 & 433.907 & 2 & 231.000 & .000 \\
\hline 2 & 3 & .186 & 3 & 1 & 232 & 335.891 & 3 & 230.000 & .000 \\
\hline 3 & 4 & .141 & 4 & 1 & 232 & 347.515 & 4 & 229.000 & .000 \\
\hline 4 & 5 & .135 & 5 & 1 & 232 & 292.223 & 5 & 228.000 & .000 \\
\hline 5 & 6 & .128 & 6 & 1 & 232 & 257.307 & 6 & 227.000 & .000 \\
\hline 6 & 7 & .120 & 7 & 1 & 232 & 236.366 & 7 & 226.000 & .000 \\
\hline
\end{tabular}

\section{Discussion}

Our result habitat features such as the slope position, concealment, and anthropogenic factors mainly influenced the reindeers in selection of their habitat in the summer season in the unprotected forest habitat of the study area (Fig. 2). The animal habitat selection is a compre- 


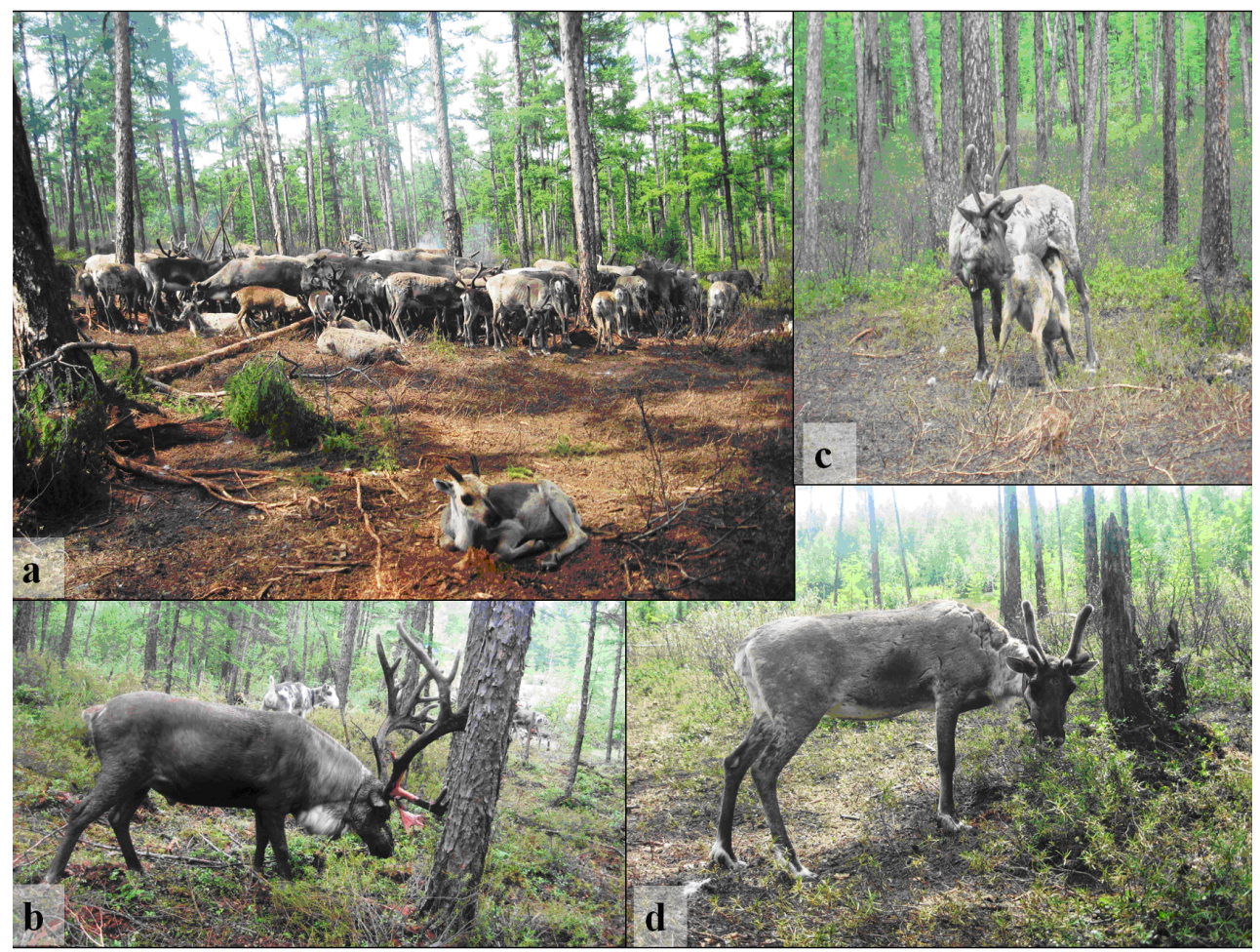

Fig. 2. Showing reindeer and its habitat at study area a) reindeer herd, b) male reindeer in habitat, c) female and newborn, d) female reindeer in habitat (๔ author: Prof. Xiuxiang Meng, 2013).

hensive countermeasure of animals adapting to the environment. The genetic characteristic and physiological property of an animal, climate, habitat properties, food, shelter, bunker, pressure of predation, and competition, all affect the habitat selection function of animals (Noel et al., 1998; Chu et al., 2009; Aryal et al., 2010, 2013, 2014a). Reindeers avoid the anthropogenic-affected areas, and similar results have been reported in other studies (Nellemann, Cameron, 1996; Vistnes, Nellemann, 2001; Pharo, Vitt, 2000). The study area (i.e., Aoluguya) is a famous tourist attraction, with summer (from June to October) being the peak tourist season with high level of tourism-related activities (Helle, Särkelä, 1993; Nelleman, Cameron, 1996; Dyer et al., 2001; Vistnes et al., 2001). The local people of this area largely depend on the forest product resources such as bee herding, collecting wild vegetables, hunting, poaching, and grazing; these activities highly influence the reindeer habitat and its behaviours, and the reindeers try to avoid such anthropogenic-affected areas.

The availability of feeding species of reindeer such as lichen as the main food source and the rising temperature of this region has largely influenced the forest production and lichen production, as lichen growth is dependent on low temperature and forest canopy (Frid, Dill, 2002). Our study suggested that food availability and canopy cover were significantly greater 
in the use area as compared to that in the non-use area; therefore, these factors are also responsible for habitat selection of reindeer. Therefore, this study has confirmed that reindeers are forced to choose poor habitat because of their distribution in unprotected areas has high human interference or disturbance. These factors should be considered by the concerned authority or agency to manage the reindeer population in the wild.

\section{Acknowledgements}

This research was supported by the Fundamental Research Funds for the Central Universities and the Research Funds of Renmin University of China (15XNLQ02), the "Fund for building world-class universities (ecology) of Renmin University of China" and Nature Science Foundation of China (31672300). We thank anonymous referees for comments that improved the manuscript.

\section{References}

Aryal, A., Raubenheimer, D., Subedi, S. \& Kattel B. (2010). Spatial habitat overlap \& habitat preference of Himalayan musk deer 'Moschus chrysogaster' in Sagarmatha (Mt. Everest) National Park, Nepal. Current Research Journal of Biological Sciences, 2(3), 217-225.

Aryal, A., Raubenheimer, D. \& Brunton D. (2013). Habitat assessment for the translocation of blue sheep to maintains a viable snow leopard population in the Mt Everest Region, Nepal. Zoology and Ecology, 23(1), 66-82. DOI: $10.1080 / 21658005.2013 .765634$.

Aryal, A., Brunton, D. \& Raubenheimer D. (2014a). Impacts of climate change on human-wildlife- ecosystem interactions in the Trans-Himalayan region of Nepal. Theor. Appl. Clim., 115(3-4), 517-529. DOI: 10.1007/s00704013-0902-4.

Aryal, A., Raubenheimer, D., Ji, W. \& Brunton D. (2014b). Blue sheep in the Annapurna Conservation Area, Nepal: habitat use, population biomass and their contribution to the carrying capacity of snow leopards. Integrative Zoology, 9, 34-45, DOI: 10.1111/1749-4877.12004.

Banfield, A.W.F. (1961). A revision of the reindeer and caribou genus rangifer. Bulletin of National Museum of Canada, 177, 1-137. https://lib.ugent.be/catalog/rug01:000836936

Boyce, M.S., Vernierb, P.R., Nielsena, S.E. \& Schmiegelow F.K.A. (2002). Evaluating resource selection functions. Ecol. Model., 157, 281-300. DOI: 10.1016/S0304-3800(02)00200-4.

Chen, Z.J. (1985). Protection and utilization of wildlife resources in GenHe (in Chinese). Natural Resources Study, 4, 35-40.

Chu, H.J., Jiang, Z.G., Jiang, F., Ge, Y., Tao, Y.S. \& Li B. (2009). Summer and winter bed-site selection by Goitred Gazelle (Gazella subgutturosa sairensis) (in Chinese). Zool. Res., 30(3), 311-318. DOI: 10.3724/SP.J.1141.2009.03311.

Dyer, S.J., O’Neill, J.P., Wasel, S.M. \& Boutin S. (2001). Avoidance of industrial development by woodland caribou. J. Wildl. Manag., 65, 531-542. DOI: 10.2307/i293832.

Feng, C. \& Bai X.L. (2011). The bryophyte consumed by reindeers and species diversity of bryophyte in reindeer habitats (in Chinese). Acta Ecologica Sinica, 31(13), 3830-3838.

Frid, A. \& Dill L. (2002). Human-caused disturbance stimuli as a form of predation risk. Conserv. Ecol., 6(1), 11.

Helle, T. \& Särkelä M. (1993). The effect of outdoor recreation on range use by semidomesticated reindeer. Scand. J. For. Res., 8, 123-133. DOI: 10.1080/02827589309382761.

Henttonen, H. \& Tikhonov A. (2008). Rangifer tarandus. In IUCN 2013. IUCN Red List of Threatened Species. Version 2013.1. <www.iucnredlist.org>.

Jiang, Z.G. (2004). Principles of animal behavior and species protection methods (in Chinese). Beijing: Science Press.

Li, Y.Z. (1988). Reindeers are hard to find in vast Xing'anling mountains (in Chinese). Chinese Wildlife, 1, 35-37.

Liao, Z.M. \& Xie Y.X. (2011). The economic reasons and difficulties of the Institutional change (in Chinese). Journal of China Agricultural University, 28(3), 58-65.

Ma, Y.C. (1986). The management and utilization of reindeer in China. Rangifer, 1, 345-346.

Manly, B.F.J., McDonald, L.L., Thomas, D.L., McDonald, T.L. \& Erickson W.P. (2002). Resource selection by animals, statistical design and analysis for field studies. Dordercht: Kluwer Academic Publication.

Nelleman, C. \& Cameron R. (1996). Effects of petroleum development on terrain preferences of calving caribou. 
Arctic, 49, 23-28.

Noel, L.E., Pollard, R.H., Ballard, W.B. \& Cronin M.A. (1998). Activity and use of active gravel pads and tundra by caribou, Rangifer tarandus granti, within the Prudhoe Bay oil field, Alaska. Can. Field-Nat., 112, 400-409.

O'Brien, D., Manseau, M., Fall, A. \& Fortin M.-J. (2006). Testing the importance of spatial configuration of winter habitat for woodland caribou: an application of graph theory. Biol. Conserv., 130, 70-83. DOI: 10.1016/j.biocon.2005.12.014.

Orians, G.H. \& Wittenberger J.F. (1991). Spatial and temporal scales in habitat selection. Am. Nat., 137, s29-s49.

Pharo, E. \& Vitt D. (2000). Local variation in bryophyte and macro-lichen cover and diversity in montane forests of wesern Canada. American Bryological and Lichenological Society, 103, 455-466. DOI: 10.1639/0007-2745(2000)103[0455:LVIBAM]2.0.CO;2.

Skarin, A., Danell, Ö., Bergström, R. \& Moen J. (2004). Insect avoidance may override human disturbances in reindeer habitat selection. Rangifer, 24, 95-103. DOI: 10.7557/2.24.2.306.

Tang, G. (2008). The plight and countermeasures for Ewenki's reindeer breeding (in Chinese). Heilongjiang National Series, 6, 129-134.

Vistnes, I. \& Nellemann C. (2001). Avoidance of cabins, roads, and power lines by reindeer during calving. J. Wildl. Manag., 65, 915-925.

Vistnes, I., Nellemann, C., Jordhøy, P. \& Strand O. (2001). Wild reindeer: Impacts of progressive infrastructure development on distribution and range use. Polar Biol., 24, 531-537. DOI: 10.1007/s003000100253.

Wang, Y.Y. (1995). The reindeers and breeding of Ewenki people in the northeast China (in Chinese). Heilongjiang National Series, 4, 95-97.

Xiang, H. (2008). The status, confusion, thinking: the investigation and reflection about the existence and development of economy of Aoluguya Ewenki people (in Chinese). Heilongjiang National Series, 3, 155-159.

Yin, R.X., Wu, J.P., Wang, J. \& Liu S.W. (1999). The reindeer in China (in Chinese). Chinese Wildlife, 20(4), 34-34. 